she refuses. Her father curses her and she, together with her younger sister, runs away to a distant relation on the Gold Coast. The girls on their flight are seized by the Portuguese slave-dealer, but the second lover has with some friends gone in search of her and in a heavy fight they redeem the girl. They all turn homeward in triumph, the parents are easily reconciled, and nothing stands in the way of a happy ending. Before, however, this comes to full realization the misdeeds of the prodigal have been discovered and he is sentenced to death, the secret servants of justice appear, singing their song, 'We come by night, we go by night', and beating the death-drum over the culprit. He is buried in the ground, only his head remaining above the surface, and is left to die. But the second lover, who has just returned from his adventure with the slave-dealer, rescues his rival, who had been his friend, from his terrible interment and helps him to escape to Dahomey.

The picture of African life given in the drama is true in every detail. The language is of a richness, a force, and a fluency such as the writer of this note has never before met in Ewe. It is a true work of fiction based on reality and contains passages of genuine poetry. The manuscript won a second prize in the competition of the Institute for books by Africans. The author is to be congratulated on his achievement.

The author of the second book, a Twi Grammar, is C. A. Akrofi. I Twi Kasa Mmara means 'The Laws of the Twi Language', this being the author's rendering of ' Grammar'. It is a book intended primarily for native readers and as such has its appropriate place besides Christaller's classical grammar of the language. Mr. Akrofi is a real scholar; his book is the result of prolonged independent investigation. He has gained an insight into the inner structure of his mother tongue as few others have, whether European or African. In many details he goes his own way and succeeds in shedding fresh light on the language. His rules are illustrated by numerous and well-chosen examples. In certain sections, such as that dealing with intonation, his description is incomplete, but this is excused by the fact that for natives a study of the laws of intonation is of less importance than for Europeans. It may be regretted that so few Europeans will be able to read the book, but those who do read it will be rewarded for their trouble. They will not only understand the language better, but will also learn how an educated African with a scientific mind is able to give an account of his own speech.

\title{
Hausa Orthography
}

When in 1934 Dr. G. P. Bargery published his Hausa Dictionary he based the orthography of the language on the recommendations of this Institute,

I Twi Kasa Mmara. London: Longmans; Accra: Scottish Mission Book Depot. Pp. I10. 2s. $6 d$. 
with the provision, however, that the ejective consonants should be represented by an apostrophe following the letter, and the implosives by an apostrophe preceding the letter. This proved to be inconvenient in writing, and these letters have therefore now been replaced by special letters which avoid the apostrophe. The new symbols add a curl to the respective letters, so that they have the following forms: $k, b, d$. The capital forms are $\mathrm{K}, \mathrm{B}, \mathrm{D}$.

In all other respects the system employed in Bargery's Dictionary is followed, including the $c$ for $c h$.

The Kano dialect is accepted as the standard in all official publications. An occasional departure from this rule is, however, allowed, for instance where a word is peculiar to Kano Emirate only and an alternative form is in more general use, and also in the use of certain grammatical forms.

The new orthography will be used in all future Government publications, and it is to be hoped that missionary societies and other bodies or individuals will likewise adopt it. A new series of readers written in the new orthography is in course of preparation. These and others will gradually replace the books written on previous systems.

The following short text from a book recently published will show how the new script looks, and it will convince every student of Hausa that it is a great improvement on all preceding systems :

Bayan kamar kwana bakwai, da sarkin yaki ya ga lalle Barde ya warke, sai ya ce ya yi tsalle ya gani. Ya yunkura, ya yi tsalle, ya buga kafa, ya dube shi, ya durkusa ya ce, 'Allah ya taimake ka yadda ka taimake ni.'

Sarkin yaki ya ce, 'Alhamdulillahi, tun da ka warke! Sai ya nufi cikin gida, ya d'auko masu guda biyu, ya fito da su wajen Barde', ya ce, 'Mu je bayan gari yawo, mu shawo iska.' Barde ya ce, 'To.' Ya karbi masu ya rike, har suka isa bayan gari.

$\mathrm{Da}$ isarsu sai sarkin yaki ya ce masa, ' ZaBi daya.'

Barde ya ce, 'Me za mu yi da su?'

Sarkin yaki ya ce, 'Kai dai zabi d'aya, na ce, Ya zabi guda gajere, ya mika masa dogon.'

Ko da ya karba, sai ya ce masa ya tsaya nan, shi ya ja da baya ka dan su yi yaki. Yaki ko na sosai, ba wasa ba, kowa ya sami danuwansa ya kashe.

Da Barde ya ji haka, sai ya yar da nasa mashin, ya ja da baya, ya ce, 'Subuhanalillahi, Allah ya sawwaka in yi yaki da kai!'

Sarkin yaki ya ce, 'Ko kana kasa kana dabo, sai ka yi. Cikin yakin da muka yi da ku watan jiya ina da d a, kai ka sa mashi ka tsire shi. Na neme ka kasa da bisa lokacin nan, na rasa, sai daga baya har an yi maka raunuka za a kashe, na gan ka, na ga in na kashe ka sa'an nan ban nuce ba, don lokacin nan kusa da matacce ka ke. Saboda haka na ce a kyale ka, na jiyyace ka, sai yanzu da na ga ka warware, ka iya jin zafin da dana ya ji, na ke so in rama masa, ko da ya ke ba shi da rai. Yana kan kokarinsa ka kashe shi, saboda 
haka ni kuma na ke so in kashe ka bisa kokarinka, ba sa'ad da ka ke ba wani makami a hannunka ba. Yanzu ko kana so, ko ba ka so, sai ka d auki mashin nan ka taso mini, sa'an nan ni ko in tsire ka.'

\section{Third International Congress on Phonetic Sciences.}

This Congress, which has become the leading international centre of phonetic studies, was held at Ghent during July, and was attended by no less than 280 members from many countries. African languages and their phonetics were well represented, mainly at a special Session on Anthropology. Dr. Ida C. Ward spoke on 'Tone in West African Languages', T. E. Pardoe on 'African 'Tonal Patterns extant in present-day Afro-American Speech ', A. Basset on 'Aires phonétiques homogènes et non-homogènes' (in Berber dialects), and D. Westermann on the writing of African languages. Particular interest was shown in the click sounds in South African languages, three papers dealing with the phenomenon, viz. I. van Ginneken, 'Les Clics, les consonnes et les voyelles dans l'histoire de l'humanité '; R. Stopa, 'Die Schnalzlaute', and P. de V. Pienaar, 'Click Formation and Distribution'. While it will be generally admitted that clicks are an archaic form of human speech-sounds, van Ginneken went so far as to maintain that all languages originally used clicks only, till gradually out of them other sounds developed and finally the clicks were dropped in most languages, and to-day exist only as relics. This is an interesting hypothesis, but it will hardly be possible to prove it.

An important by-product of the Congress was the foundation of the International Society of Phonetic Sciences. The President of the new Society is Professor Daniel Jones of London, and its Journal will be the Archiv für vergleichende Phonetik published in Berlin by D. Westermann and E. Zwirner.

Royal African Society.

THE Rev. E. W. Smith, D.D., has been appointed Editor of the Journal of the Royal African Society, following the retirement of Mr. R. Nicholson, C.M.G., who had filled the dual position of Secretary and Editor of the Journal. Dr. Smith, who is a member of the Council of this Institute and is well known to readers of Africa, was for many years engaged in missionary work in Basutoland and Northern Rhodesia. He is an ex-President of the Royal Anthropological Institute and has been Editorial Superintendent of the British and Foreign Bible Society since 1933.

Mr. S. F. Deck has been appointed Secretary to the Society. He also has wide African experience and from 1920 to 1925 held the appointment of Principal Inspector of Labour, in which capacity he travelled widely in 